\section{A Network-based Approach on Opportunity Recognition}

\begin{abstract}
This paper argues that individuals differ in terms of their perception of opportunities because of the differences between the networks they are embedded in. We focus on two aspects of individuals' embeddedness in networks, that is, (1) individuals' belonging to residential areas that are more or less likely to be characterized by network cohesion, and (2) individuals' differential access to network contacts based on the level of human capital they hold. Our analyses show that the nature of one's residential area influences the perception of entrepreneurial opportunities. Further, we find a positive effect for education, i.e., people with a higher educational level are more likely to perceive entrepreneurial opportunities compared to those with a lower educational level.
\end{abstract}

KEY WORDS: entrepreneurship, networks, opportunity recognition

\section{JEL CLASSIFICATION: M13}

\section{Introduction}

Shane and Venkataraman (2000) posited that a unique aspect of entrepreneurship research pertains to the question of how individuals recognize opportunities for business creation. Prior research on entrepreneurial opportunity recognition has focused on the role of the individual,

Final version accepted on February 9, 2005

Pia Arenius

HEC Lausanne

522-BFSH-1

CH-1015 Lausanne-Dorigny

Switzerland

E-mail:pia.arenius@unil.ch

Dirk De Clercq

Vlerick Leuven Gent Management School and Ghent University

Reep 1

9000 Gent, Belgium

E-mail:Dirk.DeClercq@vlerick.be e.g., the role of her prior knowledge (Shane, 2000) and her alertness to entrepreneurial opportunities (Kirzner, 1973). In this paper, we add to the literature on entrepreneurial opportunity recognition by using a network perspective. Whereas the existing research on networks and entrepreneurship has already examined the relationship between networks and various aspects such as the creation of new firms (Johannisson and Ramirez-Passilas, 2001), resource acquisition (Birley, 1985; Aldrich and Zimmer, 1986), performance (Podolny et al., 1996) and firm survival (Reese and Aldrich, 1995; Ingram and Baum, 1997), we believe that the relationship between networks and opportunity perception has not been sufficiently addressed. In this study, we intend to fill this gap in the literature by examining how networks influence individuals' recognition of opportunities.

We build on the literature that speaks to the importance of individuals' embeddedness in networks of relationships with others (Granovetter, 1973; 1985). This literature explains that an individual's personal network consists of all people that the individual knows (Barnes, 1972), and focuses on the fact that people may differ in terms of the personal contacts they have with others (Burt, 1986). The entrepreneurship research has pointed to the importance of networks to entrepreneurs, and even argued that social networks may be the most significant source of knowledge for entrepreneurs (Johannisson, 1990). For instance, Nahapiet and Ghoshal (1998) discussed how social capital and networks create favorable conditions for the combination and exchange of knowledge, and therefore also for the creation of new knowledge. Further, it has been argued that social encounters between an individual and her network contacts may be an important source of new ideas (Christensen 
and Peterson, 1990), and networks have also been linked with the number of new opportunities perceived by entrepreneurs (Singh et al., 1999). The rationale is that an individual's network can provide access to knowledge that is not currently possessed, thus leading to the potential for opportunity recognition.

In general, prior researchers have argued that networks differ in terms of their characteristics and that these differences may reflect the extent to which effective knowledge exchange takes place (e.g., Coleman, 1988; Burt, 1992; Davidsson and Honig, 2003). Furthermore, recent research on regional topics has examined different elements that contribute to the "competence" of a region (Lawson, 1999), and special attention has been devoted to the opportunity for new knowledge generation based on the combination of existing knowledge bases (Lawson and Lorenz, 1999). In this study, we argue that differences among individuals in terms of the network they are embedded in, affect the likelihood for opportunity recognition. We examine two aspects of individuals' embeddedness in networks. First, we focus on differences across individuals in terms of the type of network they belong to. More specifically, we look at the cohesiveness of the network individuals belong to. Second, we examine individual differences in opportunity recognition in terms of the extent to which individuals are potentially exposed to network contacts. More specifically, we argue that an important mechanism through which individuals' human capital affects opportunity recognition pertains to the potential access to network contacts.

\section{Theoretical background}

\subsection{Network cohesiveness}

Entrepreneurship is an activity that involves the discovery, creation and exploitation of opportunities aimed at the introduction of, e.g., new goods and services, new ways of organizing, or new processes (Venkataraman, 1997; Shane and Venkataraman, 2000). In this paper, we focus on the first part of the entrepreneurial process, namely on opportunity discovery. We adopt the Kirznerian (1973) view to opportunity recognition according to which entrepreneurial opportu- nities arise from individuals' differential access to information. That is, people discover opportunities through the recognition of the value of new information that they are exposed to (Shane, 2000). We argue that an important reason for why some people are more likely to be exposed to new information and therefore to perceive entrepreneurial opportunities results from the different structure of the network they are embedded in.

The network literature suggests that individuals gain access to information through interaction with other people, who in turn are linked to others, and that network characteristics influence the availability, timing and quality of information access. To date, the literature on individuals' embeddedness in networks has offered two views, i.e., Burt's (1992) structural hole argument and Coleman's (1990) network closure argument. Both views build on the assumption that the nature of networks affects the flow of information among individuals, and therefore the extent to which individuals can use this information to beneficial ends. However, the two views provide a contrasting perspective on how networks affect individuals' access to information. We will develop two competing hypotheses, then, relating network structure to individuals' perception of opportunities. More specifically, the focus will be on the cohesiveness of individuals' networks, i.e., the extent to which one's network is mainly characterized by weak ties and structural holes (i.e., low cohesive networks) versus strong ties (i.e., high cohesive networks).

Burt's (1992) structural hole argument builds on the notion of the "strength of weak ties" as originally developed by Granovetter (1973). Granovetter (1973) argued that new information is more easily obtained through casual acquaintances (weak ties) than through close personal friends (strong ties). More specifically, he posited that given the high maintenance costs associated with close relationships, there exists a maximum in the number of "strong ties" one can have with others. However, it is possible for individuals to have many "weak ties" within their social network (Granovetter, 1973). Furthermore, Granovetter (1973) argued that because an individual does not interact with weak ties on a regular basis, weak ties may give better access to unique 
information compared to strong ties. Thus, based on the above and since we maintain that the perception of entrepreneurial opportunities requires new information, we reason that individuals who possess more weak ties are more likely to perceive entrepreneurial opportunities compared to individuals who possess less weak ties.

Burt (1992) extended Granovetter's argument by further explaining that a network tie provides access to new information if the tie is non-redundant, i.e., if it spans a structural hole. Burt (1992) explained that network ties between two individuals are redundant if they are structurally equivalent (i.e., the individuals have the same contacts) and cohesive (i.e., the relationship is characterized by emotional closeness). He argued that network ties are more likely to be functional and provide access to new information if they are non-redundant. Consequently, networks rich of structural holes are more likely to yield new information, which can lead then to the discovery of entrepreneurial opportunities. Burt (1992) also pointed out that the information benefits stemming from structural holes are a product of both primary and secondary structural holes. Whereas primary holes pertain to a person's direct contacts, secondary holes pertain to his or her secondary contacts (i.e., relationships between the direct contacts and third parties). In other words, the notion of individuals' secondary network (which potentially includes "secondary holes") speaks to how network characteristics at the regional level may affect the network configuration individuals are confronted with. Furthermore, Burt argued that these secondary structural holes are most likely to exist in networks characterized by low cohesion (Burt, 1992). Based on the above arguments, we hypothesize:

Hypothesis 1a: Individuals who are embedded in less cohesive networks are more likely to recognize opportunities compared to individuals who are embedded in more cohesive networks.

An alternative view on networks and their provision of information was provided by Coleman who advanced his "network closure argument" (Coleman, 1988, 1990). Coleman pointed out that close interactions with others are valuable in terms of the quality of the information that is provided (Coleman, 1990). For example, a social scientist who is interested in being up-to-date in terms of research in related fields can benefit from her everyday interactions with colleagues, given that these colleagues are reliable exchange partners (Coleman, 1990: 310).

Coleman argued that network cohesion encourages people's access to information in a timely manner and at the same time in a manner that improves the accuracy of information retrieval (Coleman, 1988). Dense networks of strong ties facilitate the flow of information between individuals as they imply obligations and mutual understanding among individuals, and therefore a reduced risk of uncertainty. Empirical support for this notion has been found in the literature on interpersonal and interfirm relationships, which showed that when a relationship is predicated on a belief in the other's goodwill, the need to establish monitoring activities to protect oneself against the other's opportunistic behavior becomes less relevant, and the parties will be more likely to engage in extensive communication and to learn from one another (Zaheer et al., 1998).

Following Coleman's arguments, we would expect that networks with a high level of cohesion are thus effective rather than ineffective in terms of the generation of new knowledge and ideas. In other words, individuals embedded in more cohesive networks would be more likely to generate opportunities for new business creation compared to individuals who belong to less cohesive networks. The above arguments lead to the following hypothesis.

Hypothesis 1b: Individuals who are embedded in more cohesive networks are more likely to recognize opportunities compared to individuals who are embedded in less cohesive networks.

\subsection{Human capital}

In the above paragraphs, we hypothesized how differences among individuals in terms of the nature of the network they are embedded in affect the perception of opportunities. In the following paragraphs, we argue that differences among individuals in terms of their human capital are also important to explain differences in opportunity 
recognition (Shane, 2000; Shane and Venkataraman, 2000). We hereby reason that one important, but not the only, mechanism through which human capital affects opportunity recognition is individuals' overall exposure to network contacts. More specifically, whereas the hypotheses given above pertain to individual differences in terms of the type of network one belongs to (i.e., the cohesiveness of the network), the following hypotheses pertain more generally to individual differences in terms of the extent to which individuals are potentially exposed to network contacts. More specifically, we argue that, besides other mechanisms, an important mechanism through which individuals' human capital affects opportunity recognition pertains to the potential access to network contacts.

The role of human capital in explaining individuals' behavior dates back to Becker's (1964) work in which the idea was advanced that factors such as education and experience are important aspects in economic analysis, just like equipment or other material assets. Becker (1964) argued that human capital is comprised of attributes which can be associated with individuals' behavior and success; in this study we examine the influence of individuals' human capital in the opportunity discovery process. More specifically, we examine two dimensions of individuals' human capital that may influence the access to network resources, and thus increase opportunity recognition, i.e., education and work status. Education and workplace experience indeed are indicators of human capital that have been used in labor force participation analyses, and these dimensions have been associated with the behavior and success of (potential) entrepreneurs (Evans and Leighton, 1989; Bates, 1997; Greene, 2000).

\subsubsection{Education}

The existing literature on education and opportunities has focused more on the exploitation of opportunities (i.e., actual business creation) rather than the discovery of opportunities by potential entrepreneurs. For instance, it has been argued that educational credentials may make it easier to find employment which entails working for others, thereby reducing the motivations to engage in self-employment (Bates, 1995; Bates and Servon, 2000). Shane and Venkataraman (2000) argued that individuals' propensity to exploit opportunities depends on factors such as the trade-off between the value of the opportunity versus the cost to create that value, as well as individual differences in terms of risk propensity and optimism. However, before opportunities can be realized, they first need to be discovered. The focus of this paper is on the latter rather than the former aspect. That is, we provide several arguments for why individuals' differences in terms of education play an important role in explaining the discovery of new ideas.

First, there is a network argument that relates education to opportunity recognition. Whereas prior research has often focused on how access to resources is important after opportunities for business creation have been recognized (Stevenson and Jarillo, 1990), we argue that opportunities are recognized by some individuals and not by others based on their differential access to resources. More specifically, we reason that individuals' education may enhance opportunity recognition through the facilitation of access to knowledge, e.g., connections to other "knowledgeable" others such as alumni network contacts (Cohen and Levinthal, 1990; Burt, 1992). Therefore, one important role of human capital played in stimulating entrepreneurship pertains to one's access to information necessary to discover opportunities in the market place.

Second, we argue that individuals' educational level will positively affect the likelihood to perceive opportunities because highly-educated individuals have a broader knowledge base to draw from and thus a higher likelihood that they can relate this knowledge to potential entrepreneurial opportunities (Cohen and Levinthal, 1990). Although one could argue that in some cases an expanded knowledge base may lead to market myopia and a difficulty to "unlearn" existing behavior (Prahalad and Bettis, 1986), we reason that education may provide knowledge that is complementary with new information included in entrepreneurial opportunities, and therefore enhance opportunity recognition. Shane and Venkataraman (2000) already emphasized the importance of one's knowledge base in the opportunity recognition process. More specifi- 
cally, they reasoned that individuals' prior knowledge strongly contributes to their ability to recognize opportunities in that such knowledge creates mental schemas from which new information can be recognized and processed (Shane and Venkataraman, 2000). Therefore, since individuals do not possess the same knowledge, they will differ in their ability to recognize the potential of opportunities. Furthermore, a related argument for why individuals' educational credentials may increase the discovery of opportunities is that highly-educated individuals have more self-confidence to possess the capabilities to come up with good ideas for new venture creation (Bandura, 1978).

Based on the arguments given above, we contend that there is a positive relationship between individuals' educational level and the likelihood to perceive opportunities.

Hypothesis 2: Individuals with higher educational levels are more likely to recognize opportunities compared to individuals with lower educational levels.

\subsubsection{Work status}

The reasoning for the relationship between individuals' work status and opportunity recognition is similar to the one given above for education. We hypothesize that someone's work status positively affects the likelihood to be exposed to a wider set of knowledge, and thus, to perceive opportunities for business creation. We define work status in terms of whether the individual plays an active versus passive role in the labor market; an active role could include one's participation in the work force as employee or employer, whereas a passive status may include unemployment. We reason that people with an active work status will have more opportunities to develop valuable contacts, compared to people who are "outside" the working system (Burt, 1992). First, the work place may form a natural environment for opportunity recognition, since this environment allows people to spot new opportunities in their own or contiguous industries. Furthermore, the work place constitutes a setting conducive to building network contacts based on professionally oriented relationships (Nahapiet and Ghoshal, 1998). Individuals who are not part of the active economic system will be less likely to build such network contacts. Therefore, we hypothesize that individuals who have an active work status will be more likely to perceive opportunities compared to others who are not part of the working system.

Hypothesis 3: Individuals with an active work status are more likely to recognize opportunities compared to individuals with a passive work status.

\section{Methodology}

\subsection{Sample}

Our analyses are undertaken on a representative sample of the adult population in two countries, Belgium and Finland. Our unit of analysis pertains to the individual level, and we used data collected as part of the 2002 Global Entrepreneurship Monitor (GEM) study. We collected data in Belgium and Finland with telephone interviews during the Summer of 2002 using a standardized questionnaire translated from English into the native language(s) of each country (i.e., Dutch and French for Belgium; Finnish for Finland). A representative sample of the adult population was surveyed (for Belgium $\mathrm{N}=4057$ and for Finland $\mathrm{N}=2005)$. In this paper, we focus on those respondents who are members of the labor force (i.e., those between 18 and 64years-old at the time of the interview). This led to a total number of 3102 eligible responses in Belgium and 1434 in Finland. In order to assure that the respondents correctly reflected the population from which they were drawn, GEM assigns each respondent a weighting factor that takes into account gender and age. More specifically, the age and gender distribution of the samples were compared to the U.S. Census International Database 2002 and weights were calculated in order to match our sample to this standardized source of population structure estimates. Further, the weights were also adjusted according to the country to which the respondent belonged, i.e., the weights were normalized among the Belgian and Finnish respondents respectively. More information about the GEM study and its methodology will be provided in Reynolds et al. (2005). 


\subsection{Measures}

In the following paragraphs, we explain how we operationalized the different variables. A short description of the variables and their measurement is also given in the Appendix.

\subsubsection{Dependent variable}

Opportunity recognition: We asked the respondents whether "in the next six months there would be good opportunities for starting a business in the area where they lived." This measure is a binary variable $(1=$ Yes, $0=$ No).

\subsubsection{Predictor variables}

Nature of residential area: In this paper we use the "nature of the residential area" to which the individual belongs as a proxy for the network cohesion variable. Our measure of residential area has three categories: (1) "rural location", (2) "urban location", and (3) "big agglomerate". The allocation of the respondents to these three categories was based on the population characteristics of the locations where the respondents reside. $^{1}$

We associate the category "rural location" with areas likely characterized by high network cohesiveness whereas the category "big agglomerates" reflects areas with low network cohesiveness (Niebuhr and Stiller, 2003). On one hand, we assume that rural areas are more likely to be characterized by networks with strong relationships and less structural holes among their residents. The reasoning is that the residents of rural areas are more likely to have lived in their current area for a longer period of time, so there is more potential for close relationships to have developed over time. Furthermore, since the population density in rural areas is lower than in agglomerate areas and (to a lesser extent) urban areas, it is less likely that the network in which rural residents are embedded allows for the bridging of structural holes. On the other hand, big agglomerates are more likely to be characterized by networks with weak relationships and more structural holes among their residents. Since the population size and density is high in these areas, residents are more likely to have indirect contacts with one another through third parties, and thus they are more likely to be embedded in networks with loose ties and structural holes. In short, agglomerate areas may be more likely to have extensive networks of "loose" contacts among their residents and thus their networks are characterized by a lower level of network cohesion. ${ }^{2}$

Education: The respondents were assigned to three categories in terms of their educational level: (1) some secondary education, (2) secondary degree, and (3) post-secondary degree. In the regression analyses (see further) we entered the variables as binary variables with the third category being used as the base case.

Work status: Work status was coded as a binary variable. A value of " 1 " was assigned to respondents with an "active" work status (i.e., employed on a full-time or part-time basis), and a value of " 0 " to respondents with a "passive" working status (i.e., unemployed, student, retired, or disabled).

\subsubsection{Control variables}

We also included three control variables in order to check whether our hypothesized predictor variables affect the level of opportunity recognition beyond the impact of these controls. Age was measured as a continuous variable (ranging between 18 and 64). Gender is a binary variable: male respondents were assigned a value of " 0 ", and female respondents a value of "1". Finally, in the analysis on the whole sample (i.e., Belgium and Finland, see further) we included a binary variable to control for the country in which the respondent resided (" 0 " for Belgium and " 1 " for Finland).

\subsection{Data analysis}

We formally tested our hypotheses using binominal logistic regression models. The binominal logistic regression estimates the probability of an event happening which, in our case, is the presence or absence of opportunity recognition. Since our dependent variable is discrete, we could have used an ordinary least squares regression to fit a linear probability model. However a linear probability model is heteroskedastic and may predict probability values beyond the $(0,1)$ range (Stynes and Peterson, 1984; Greene, 1997).

In order to test our hypotheses, we ran two binominal logistic regression models on the 
different samples. Whereas Model 1 includes only the control variables, Model 2 contains the predictor variables along with the control variables. In assessing the overall adequacy of the model and the significance of the individual variables, we used the instructions of Hosmer and Lemeshow (2000). We assessed the goodness of fit of the models using the Model $\chi^{2}$ test. The Model $\chi^{2}$ is the difference between the $-2 \mathrm{LL}$ (minus two times the log likelihood of the model) of the fitted model and the $-2 \mathrm{LL}$ of the null hypothesis model. We further report the Nagelkerke-statistic, which indicates the variance explained by our models, as well as the overall rate of correct classification of the models. In order to test whether the addition of the predictor variables led to a significant improvement of the model, we examined the Block $\chi^{2}$ test. The Block $\chi^{2}$ is the difference between the -2 LL (minus two times the log likelihood of the model) of the full model and the $-2 \mathrm{LL}$ of the control model.

In order to test the significance of the individual regression coefficients, we used the Wald test. In order to make the interpretation of the results easier, we also report the odds ratio [i.e., $\operatorname{Exp}(\beta)$ ] for each of the predictor variables. The odds ratio is the exponent of the regression coefficient. For binary variables, it approximates how much more likely (or unlikely) it is for the outcome (i.e., opportunity recognition) to be present among those respondents with a predictor value equal to one compared to respondents with a predictor value equal to zero. For example, in the case of "gender" as predictor variable
$(0=$ male, $1=$ female $)$ a value of $\operatorname{Exp}(\beta)=0.50$ would mean that women are half as likely to perceive opportunities compared to men.

We ran three sets of binomial logistic regression analyses, one for the pooled data (i.e., Belgium and Finland, Table II), and one for each of the countries separately (Tables III and IV). Preliminary examination of the data had indicated that the overall level of opportunity perception was much higher in Finland compared to Belgium. In Finland, 51.2\% of all respondents perceived good opportunities to start a business, compared to only $16.7 \%$ in Belgium $(F=914.52$, d.f. $=3584, \quad P<0.001) \quad$ Therefore, we also wanted to test whether our findings were consistent between "high-opportunity" versus "lowopportunity" countries. Furthermore, preliminary cross-tabulation analyses indicated that the differences in opportunity recognition were significant across regions in Finland but not in Belgium. Therefore, the country-specific analyses (Tables III and IV) could indicate to what extent country-related differences may influence the relationship between residential areas and opportunity recognition. In the analyses on the pooled data, we included a "country" dummy variable to control for country effects (Table II).

\section{Results}

Table I reports the descriptive statistics of the variables and the results of the correlation analysis. It can be seen that our average respondent is 41 years and has a secondary or above secondary

Table I

Correlation table

\begin{tabular}{|c|c|c|c|c|c|c|c|c|}
\hline & Mean & 1 & 2 & 3 & 4 & 5 & 6 & 7 \\
\hline $\begin{array}{l}\text { Opportunity } \\
\text { recognition }\end{array}$ & 0.3 & 1.000 & & & & & & \\
\hline Age & 40.6 & -0.007 & 1.000 & & & & & \\
\hline Gender & 0.5 & $-0.077 * * *$ & 0.027 & 1.000 & & & & \\
\hline Country & 0.3 & $0.354 * * *$ & 0.018 & 0.004 & 1.000 & & & \\
\hline $\begin{array}{l}\text { Nature of } \\
\text { residential area }\end{array}$ & 2.2 & $0.176^{* * *}$ & -0.030 & 0.027 & $0.277 * * *$ & 1.000 & & \\
\hline Education & 2.3 & $-0.114 * * *$ & $-0.132 * * *$ & $-0.041 * *$ & $-0.231 * * *$ & $-0.069 * * *$ & 1.000 & \\
\hline Work status & 0.7 & 0.026 & $-0.050 * * *$ & $-0.182 * * *$ & 0.020 & -0.023 & 0.003 & 1.000 \\
\hline
\end{tabular}

* significant at $P \leq 0.05$.

** significant at $P \leq 0.01$.

$* * *$ significant at $P \leq 0.001$. 
Table II

Results of the logistic regression analyses (dependent variable: opportunity recognition) (pooled sample)

\begin{tabular}{|c|c|c|c|c|c|c|c|}
\hline \multirow[t]{2}{*}{ Variables } & \multirow{2}{*}{$\begin{array}{l}\text { Variable } \\
\text { categories }\end{array}$} & \multicolumn{3}{|l|}{ Model 1} & \multicolumn{3}{|l|}{ Model 2} \\
\hline & & $\begin{array}{l}\text { Coefficient } \beta \\
\text { S.E. }\end{array}$ & Wald & $\operatorname{Exp}(\beta)$ & $\begin{array}{l}\text { Coefficient } \beta \\
\text { S.E. }\end{array}$ & Wald & $\operatorname{Exp}(\beta)$ \\
\hline Age & & $\begin{array}{l}-0.002 \\
(0.004)\end{array}$ & 0.431 & 0.998 & $\begin{array}{c}0.001 \\
(0.004)\end{array}$ & 0.046 & 0.999 \\
\hline Gender & $\begin{array}{l}(0=\text { Male } \\
1=\text { Female })\end{array}$ & $\begin{array}{l}-0.327^{* * *} \\
(0.093)\end{array}$ & 12.260 & 0.721 & $\begin{array}{l}-0.375^{* * *} \\
(0.096)\end{array}$ & 15.146 & 0.687 \\
\hline Country & $\begin{array}{l}(0=\text { Belgium } \\
1=\text { Finland })\end{array}$ & $\begin{array}{l}1.603^{* * *} \\
(0.092)\end{array}$ & 295.804 & 4.968 & $\begin{array}{l}1.483^{* * *} \\
(0.099)\end{array}$ & 225.616 & 4.406 \\
\hline \multirow[t]{3}{*}{$\begin{array}{l}\text { Nature of } \\
\text { residential area }\end{array}$} & $\begin{array}{l}\text { Big agglomerate } \\
\text { (base case) }\end{array}$ & & & & & 15.749 & 1.000 \\
\hline & $\begin{array}{l}\text { Urban } \\
\text { location }\end{array}$ & & & & $\begin{array}{l}-0.375^{* *} \\
(0.123)\end{array}$ & 9.244 & 0.687 \\
\hline & $\begin{array}{l}\text { Rural } \\
\text { location }\end{array}$ & & & & $\begin{array}{l}-0.390^{* * *} \\
(0.113)\end{array}$ & 11.946 & 0.677 \\
\hline \multirow[t]{3}{*}{ Education } & $\begin{array}{l}\text { Post secondary } \\
\text { (base case) }\end{array}$ & & & & & 20.676 & 1.000 \\
\hline & $\begin{array}{l}\text { Secondary } \\
\text { degree }\end{array}$ & & & & $\begin{array}{l}-0.463^{* * *} \\
(0.104)\end{array}$ & 19.749 & 0.629 \\
\hline & $\begin{array}{l}\text { Some } \\
\text { secondary }\end{array}$ & & & & $\begin{array}{c}-0.348^{*} \\
(0.151)\end{array}$ & 5.300 & 0.706 \\
\hline $\begin{array}{l}\text { Work } \\
\text { status }\end{array}$ & & & & & $\begin{array}{c}-0.122 \\
(0.105)\end{array}$ & 1.338 & 0.885 \\
\hline Constant & & $\begin{array}{l}-2.626^{* * * *} \\
(0.241)\end{array}$ & 119.070 & 0.072 & $\begin{array}{l}-1.809^{* * *} \\
(0.333)\end{array}$ & 29.536 & 0.164 \\
\hline $\begin{array}{l}\text { Model } \chi^{2} \\
\text { [d.f.] }\end{array}$ & & $\begin{array}{l}322.264 * * * \\
{[3]}\end{array}$ & & & $\begin{array}{l}363.585 * * * \\
{[8]}\end{array}$ & & \\
\hline $\begin{array}{l}\text { Block } \chi^{2} \\
\text { [d.f.] }\end{array}$ & & & & & $\begin{array}{l}41.321 * * * \\
{[5]}\end{array}$ & & \\
\hline $\begin{array}{l}\text { Nagelkerke } \\
\mathrm{R}^{2}\end{array}$ & & 0.167 & & & 0.187 & & \\
\hline $\begin{array}{l}\% \text { correct } \\
\text { predictions }\end{array}$ & & 70.5 & & & 73.3 & & \\
\hline
\end{tabular}

* significant at $P \leq 0.05$.

** significant at $P \leq 0.01$.

*** significant at $P \leq 0.001$.

$\dagger$ significant at $P \leq 0.10$.

level educational level. Further, women and men are equally represented in our sample.

As mentioned above, the results for the pooled sample are presented in Table II, the results for Belgium and Finland in Tables III and IV respectively. For each predictor variable, we report the maximum likelihood estimates $(\beta)$, the signifi- cance of the estimate, the estimates of the standard errors of the estimated coefficients (in parentheses), the Wald statistic, and the odds ratio $[\operatorname{Exp}(\beta)]$. Since the focus of the paper was not on the examination of country effects, we primarily used the results from the pooled sample to test our hypotheses. 
Table III

Results of the logistic regression analyses (Dependent variable: Opportunity recognition) (Belgium)

\begin{tabular}{|c|c|c|c|c|c|c|c|}
\hline \multirow[t]{2}{*}{ Variables } & \multirow{2}{*}{$\begin{array}{l}\text { Variable } \\
\text { categories }\end{array}$} & \multicolumn{3}{|c|}{ Model 1} & \multicolumn{3}{|c|}{ Model 2} \\
\hline & & $\begin{array}{l}\text { Coefficient } \beta \\
\text { S.E. }\end{array}$ & Wald & $\operatorname{Exp}(\beta)$ & $\begin{array}{l}\text { Coefficient } \beta \\
\text { S.E. }\end{array}$ & Wald & $\operatorname{Exp}(\beta)$ \\
\hline Age & & $\begin{array}{c}-0.015^{* *} \\
(0.005)\end{array}$ & 7.922 & 0.985 & $\begin{array}{l}-0.014^{* *} \\
(0.005)\end{array}$ & 6.755 & 0.986 \\
\hline Gender & $\begin{array}{l}(0=\text { Male } \\
1=\text { Female })\end{array}$ & $\begin{array}{l}-0.911^{* * *} \\
(0.139)\end{array}$ & 43.055 & 0.402 & $\begin{array}{l}-0.879 * * * \\
(0.143)\end{array}$ & 37.948 & 0.415 \\
\hline \multirow[t]{3}{*}{$\begin{array}{l}\text { Nature of } \\
\text { residential area }\end{array}$} & $\begin{array}{l}\text { Big agglomerate } \\
\text { (base case) }\end{array}$ & & & & & 3.517 & 1.000 \\
\hline & Urban location & & & & $\begin{array}{r}-0.348^{\dagger} \\
(0.186)\end{array}$ & 3.515 & 0.706 \\
\hline & Rural location & & & & $\begin{array}{c}-0.120 \\
(0.148)\end{array}$ & 0.655 & 0.887 \\
\hline \multirow[t]{3}{*}{ Education } & $\begin{array}{l}\text { Post-secondary } \\
\text { (base case) }\end{array}$ & & & & & 12.321 & 1.000 \\
\hline & $\begin{array}{l}\text { Secondary } \\
\text { degree }\end{array}$ & & & & $\begin{array}{l}-0.466 * * * \\
(0.140)\end{array}$ & 11.071 & 0.627 \\
\hline & $\begin{array}{l}\text { Some } \\
\text { secondary }\end{array}$ & & & & $\begin{array}{r}-0.574^{\dagger} \\
(0.301)\end{array}$ & 3.631 & 0.563 \\
\hline $\begin{array}{l}\text { Work } \\
\text { status }\end{array}$ & & & & & $\begin{array}{c}-0.016 \\
(0.155)\end{array}$ & 0.011 & 0.984 \\
\hline Constant & & $\begin{array}{c}0.282 \\
(0.289)\end{array}$ & 0.953 & & $\begin{array}{c}0.627 \\
(0.444)\end{array}$ & 1.987 & 1.871 \\
\hline $\begin{array}{l}\text { Model } \chi^{2} \\
\text { [d.f.] }\end{array}$ & & $\begin{array}{l}53.418^{* * *} \\
{[2]}\end{array}$ & & & $\begin{array}{l}70.425 * * * \\
{[7]}\end{array}$ & & \\
\hline $\begin{array}{l}\text { Block } \chi^{2} \\
\text { [d.f.] }\end{array}$ & & & & & $\begin{array}{l}17.007 * * \\
{[5]}\end{array}$ & & \\
\hline $\begin{array}{l}\text { Nagelkerke } \\
\mathrm{R}^{2}\end{array}$ & & 0.052 & & & 0.068 & & \\
\hline $\begin{array}{l}\% \text { correct } \\
\text { predictions }\end{array}$ & & 83.2 & & & 83.2 & & \\
\hline
\end{tabular}

* significant at $P \leq 0.05$.

** significant at $P \leq 0.01$.

*** significant at $P \leq 0.001$.

$\dagger$ significant at $P \leq 0.10$

\subsection{Pooled sample}

From Table II it can be seen that Model 2, including both the control and predictor variables, is significant at the 0.001 level (Model $\left.\chi^{2}=363.585, \quad P<0.001\right)$ and that it predicts $73.3 \%$ of the responses correctly. The significance of the Block $\chi^{2}$ indicates that the inclusion of the predictor variables in Model 2 leads to a significant improvement of the model compared to Model 1 (Block $\left.\chi^{2}=41.321, P<0.001\right)$.
Furthermore, we found that the relationship between the nature of residential area and the perception of opportunities is significant (Model 2). More specifically, individuals living in big agglomerates are more likely to perceive opportunities compared to those living in urban areas $(\beta=-0.375, P<0.01)$ and those living in rural areas $(\beta=-0.390, P<0.001)$. In other words, we find support for Hypothesis 1a (i.e., "network cohesiveness is negatively related to opportunity 
recognition") rather than the competing Hypothesis $1 b$.

Hypothesis 2 stated that people with higher educational levels are more likely to recognize opportunities than people with lower educational levels. The findings from the pooled sample support this hypothesis. Individuals with a post-secondary degree are more likely to perceive entrepreneurial opportunities compared to those with a secondary degree $(\beta=-0.463, P<0.001)$ and those with some secondary education $(\beta=-0.348, P<0.05)$.

Hypothesis 3 stated that people with an active work status are more likely to recognize opportunities compared to people with a passive work status. We find no support for this hypothesis. The coefficient of the work status variable is insignificant $(\beta=-0.122, P<0.10)$.

Table IV

Results of the logistic regression analyses (Dependent variable: Opportunity recognition) (Finland)

\begin{tabular}{|c|c|c|c|c|c|c|c|}
\hline \multirow[t]{2}{*}{ Variables } & \multirow{2}{*}{$\begin{array}{l}\text { Variable } \\
\text { categories }\end{array}$} & \multicolumn{3}{|c|}{ Model 1} & \multicolumn{3}{|c|}{ Model 2} \\
\hline & & $\begin{array}{l}\text { Coefficient } \beta \\
\text { S.E. }\end{array}$ & Wald & $\operatorname{Exp}(\beta)$ & $\begin{array}{l}\text { Coefficient } \beta \\
\text { S.E. }\end{array}$ & Wald & $\operatorname{Exp}(\beta)$ \\
\hline Age & & $\begin{array}{l}0.009^{\dagger} \\
(0.005)\end{array}$ & 3.028 & 1.009 & $\begin{array}{l}0.012 * \\
(0.005)\end{array}$ & 5.251 & 1.102 \\
\hline Gender & $\begin{array}{l}(0=\text { Male } \\
1=\text { Female })\end{array}$ & $\begin{array}{r}0.235^{\dagger} \\
(0.133)\end{array}$ & 3.133 & 1.265 & $\begin{array}{c}0.132 \\
(0.139)\end{array}$ & 0.895 & 1.141 \\
\hline \multirow[t]{2}{*}{$\begin{array}{l}\text { Nature of } \\
\text { residential area }\end{array}$} & $\begin{array}{l}\text { Big agglomerate } \\
\text { (base case) }\end{array}$ & & & & & 22.502 & 1.000 \\
\hline & $\begin{array}{l}\text { Urban } \\
\text { location } \\
\text { Rural } \\
\text { location }\end{array}$ & & & & $\begin{array}{l}-0.388 * \\
(0.172) \\
-0.842 * * * \\
(0.183)\end{array}$ & $\begin{array}{r}5.088 \\
21.247\end{array}$ & $\begin{array}{l}0.679 \\
0.431\end{array}$ \\
\hline Education & $\begin{array}{l}\text { Post-secondary } \\
\text { (base case) } \\
\text { Secondary } \\
\text { degree } \\
\text { Some } \\
\text { secondary }\end{array}$ & & & & $\begin{array}{c}-0.312^{\dagger} \\
(0.162) \\
-0.233 \\
(0.190)\end{array}$ & $\begin{array}{l}4.046 \\
3.688 \\
1.508\end{array}$ & $\begin{array}{l}1.000 \\
0.732 \\
0.792\end{array}$ \\
\hline Work status & & & & & $\begin{array}{c}-0.317^{*} \\
(0.152)\end{array}$ & 4.368 & 0.728 \\
\hline Constant & & $\begin{array}{c}-0.716^{*} \\
(0.293)\end{array}$ & 5.954 & 0.489 & $\begin{array}{c}0.215 \\
(0.417)\end{array}$ & 0.266 & 1.240 \\
\hline $\begin{array}{l}\text { Model } \chi^{2} \\
\text { [d.f.] }\end{array}$ & & $\begin{array}{l}6.222^{*} \\
{[2]}\end{array}$ & & & $\begin{array}{l}41.307^{* * *} \\
{[7]}\end{array}$ & & \\
\hline $\begin{array}{l}\text { Block } \chi^{2} \\
\text { [d.f.] }\end{array}$ & & & & & $\begin{array}{l}35.084 * * * \\
{[5]}\end{array}$ & & \\
\hline $\begin{array}{l}\text { Nagelkerke } \\
\mathrm{R}^{2}\end{array}$ & & 0.009 & & & 0.059 & & \\
\hline $\begin{array}{l}\% \text { correct } \\
\text { predictions }\end{array}$ & & 52.4 & & & 59.3 & & \\
\hline
\end{tabular}

*significant at $P \leq 0.05$.

** significant at $P \leq 0.01$.

*** significant at $P \leq 0.001$.

$\dagger$ significant at $P \leq 0.10$. 
In terms of the control variables, we found a gender effect but no age effect (Model 1, Table II). That is, men are more likely than women to perceive opportunities $(\beta=-0.327, P<0.001)$. Furthermore, as expected, we found a strong country effect: individuals living in Finland are more likely to perceive opportunities compared to their counterparts in Belgium $(\beta=-1.603, P<0.001)$.

\subsection{Country level analysis}

Table III reports the results of the logistic regression analysis on the Belgian data. The Model $\chi^{2}$ shows that Model 2, which contains both the predictor and control variables, is significant at the 0.001 level (Model $\chi^{2}=70.452, P<0.001$ ) and predicts $83.2 \%$ of the responses correctly. Based on the Block $\chi^{2}$, we conclude that the inclusion of the predictor variables leads to a significant improvement of the model (Block $\left.\chi^{2}=17.007, P<0.01\right)$.

Table IV reports the results of the logistic regression analysis on the Finnish data. The Model $\chi^{2}$ shows that Model 2 is significant at the 0.001 level (Model $\chi^{2}=41.307, P<0.001$ ) and predicts $59.3 \%$ of the responses correctly. Based on the Block $\chi^{2}$, we can also conclude that the inclusion of the predictor variables leads to a significant improvement on the model (Block $\left.\chi^{2}=35.084, P<0.001\right)$.

In terms of the role of the nature of residential area (i.e., our proxy for network cohesiveness), we found only a weak effect on the perception of opportunities (Model 2, Table III) for the Belgian data. Individuals living in an urban area are somewhat less likely to perceive opportunities compared to those living in a big agglomerate, but this finding is only weakly significant $(\beta=-0.348, \quad P<0.10)$. Surprisingly, whether one lives in a rural area or big agglomerate in Belgium does not make a difference with respect to the perception of opportunities $(\beta=-0.120$, $P<0.10)$. In contrast, for Finland we found a strong relationship between the nature of the residential area an individual belongs to and his or her perception of opportunities (Model 2, Table IV). Individuals living in an urban area are significantly less likely to perceive opportunities than those living in a big agglomerate $(\beta=-0.388, P<0.05)$, and individuals living in a rural area are significantly less likely to perceive opportunities compared to those living in a big agglomerate $(\beta=-0.842, P<0.001)$.

In terms of the role of education, the results are also somewhat different between Belgium and Finland. In Belgium, individuals with a secondary degree are significantly less likely to perceive opportunities compared to those having a postsecondary degree $(\beta=-0.466, \quad P<0.001)$ (Model 2, Table III). Furthermore, individuals with only some secondary education are also less likely to perceive opportunities compared to those with a post-secondary degree, but this difference is only weakly significant $(\beta=-0.574$, $P<0.10)$. For Finland, the relationship between education and opportunity perception is weaker than for Belgium (Model 2, Table IV). Individuals with a secondary degree are less likely to perceive opportunities compared to those having a post-secondary degree, but this result is only weakly significant $(\beta=-0.312, P<0.10)$. We find no significant difference between those having only some secondary education and those holding a post secondary degree in terms of opportunity recognition.

In terms of the role of work status, the results for the Belgian sample are consistent with the pooled sample. That is, there is no relationship between individuals having an active versus passive work status and their likelihood to perceive opportunities $(\beta=-0.016, P>0.10)$ (Model 2, Table III). However, in Finland we find a surprisingly negative effect for work status: individuals with an active work status are less likely to perceive opportunities compared to those with a passive work status $(\beta=-0.317, P<0.05)$.

Finally, in terms of the control variables, we find that in Belgium, both age and gender are significant predictors for opportunity recognition (Model 1, Table III). That is, older respondents are less likely to perceive opportunities compared to their younger counterparts $(\beta=-0.015$, $P<0.01)$, and women are less likely than men to perceive opportunities $(\beta=-0.911, P<0.001)$. For Finland, we find only very weak effects for the control variables, and in the opposite direction compared to Belgium (Model 1, Table IV). More specifically, older respondents are somewhat more likely to perceive opportunities compared to younger ones $(\beta=0.009, P<0.10)$. 
Interestingly, in Finland women are somewhat more likely to perceive opportunities compared to men $(\beta=0.235, P<0.10)$.

\section{Discussion}

In this study, we adopted a network-based approach in examining why some individuals are more likely to perceive opportunities aimed at business creation compared to others. That is, we intended to contribute to the entrepreneurship literature by applying a network view to study entrepreneurial opportunity recognition. We explained the rationale for and empirically examined why networks are important in terms of individuals' recognition of opportunities. We focused on two aspects of individuals' embeddedness in networks, that is, (1) individuals' belonging to residential areas that are more or less likely to be characterized by network cohesion, and (2) individuals' differential access to network contacts based on the level of human capital they hold. Whereas the first aspect pertains to the type of regional network one belongs to, the second aspect pertains more generally to the extent to which individuals are potentially exposed to network contacts. In terms of the role of network cohesiveness, our results suggest that individuals who reside in big agglomerates are more likely to perceive opportunities compared to their counterparts in rural areas (and this effect was much stronger in Finland compared to Belgium). In terms of the role of human capital, our results suggest that individuals' educational level, but not their work status, positively affects the likelihood to perceive opportunities. In the following paragraphs, we give some further discussion on our findings.

\subsection{Effect of network cohesion}

Before we discuss the findings pertaining to the role of network cohesion, we want to re-iterate how we operationalized this variable. In this paper we related network cohesiveness to the "nature of residential area", i.e., we associated the category "rural location" with areas high in network cohesiveness, the category "big agglomerates" with areas low in network cohesiveness, and the category "urban areas" as an intermedi- ate category (Niebuhr and Stiller, 2003). We realize that this operationalization of "network cohesiveness" is rather crude and open to discussion. For instance, as indicated in the literature, there are examples of agglomerations that are characterized by myopia and cohesiveness, which may explain why some agglomerations have shown a decline over time, such as the Ruhr Valley (Grabher, 1993). The results pertaining to the "network cohesion" construct therefore warrant extreme caution in their interpretation. That is, our findings should be interpreted more in terms of "how regional areas that differ in terms of their population structure make it more or less likely that their residents have access to new information" rather than in terms of "how very specific network structures (e.g., in terms of the number of structural holes or the absolute level of cohesiveness) affect opportunity recognition."

Despite the weakness of our measure, our finding that individuals residing in big agglomerate areas are more likely to perceive opportunities compared to individuals residing in rural and (to a lesser extent) urban areas may provide some tentative support to Granovetter's (1973) reasoning that "weak ties" can function as "bridges" to knowledge that are not included in someone's personal network of contacts. More specifically, in regional settings where it is more likely that new information will be provided through one's network (e.g., because of the higher number of possible contacts or the higher "in-stream" of new contacts), there may be more potential to perceive entrepreneurial opportunities (Niebuhr and Stiller, 2003). Furthermore, our findings in terms of the effect of "the nature of residential area" may also give some very tentative support to Burt's (1992) research on "structural holes". In short, despite the apparent weaknesses of our "cohesiveness" measure, our results could suggest that individuals who live in "big city areas" may have more possibility to broker information through their indirect network contacts, which may give them an advantage then in terms of their ability to perceive opportunities compared to individuals living in rural areas. Obviously, there may also be additional reasons why individuals in big agglomerations are more likely to perceive opportunities; for instance, the presence of various organizations (universities, research 
facilities, service providers) in more densely populated areas may provide more possibilities to discover and exchange new information.

We would also like to emphasize that our results in terms of the effect of the nature of residential area are particularly strong for Finland and not for Belgium. In other words, the variation in opportunity recognition due to the effect of residential area that we found for our total sample (Table II) seems to be driven by the Finnish (Table IV) rather than the Belgian (Table III) respondents. A possible explanation for the differential effect of residential area between Belgium and Finland may lie in the fact that Belgium is a country which is much more homogenous in terms of its regional structure compared to Finland where the differences between regions have been increasing (see footnote 3). More generally speaking, our findings suggest that countries in which there are bigger differences between "agglomerate" versus "rural" areas may show higher within-border differences in terms of how easy individuals can get access to new information and opportunities.

\subsection{Effect of human capital}

Overall, we found a positive relationship between someone's educational level and the likelihood to recognize opportunities, and this relationship was stronger for Belgium compared to Finland. More specifically, we found that individuals who have a post-secondary degree are more likely to perceive opportunities compared to those who have a lower educational degree. We provided several arguments to explain the positive effect of education, such as the increased exposure to "knowledgeable others" through networks such as alumni organizations (Burt, 1992), the broader knowledge base to draw from and thus the higher likelihood to relate current knowledge to potential entrepreneurial opportunities (Cohen and Levinthal, 1990), and the increased self-confidence to have the skills to successfully come up with new ideas for business creation (Bandura, 1978).

Further, our findings showed that someone's work status does not play an important role in the perception of entrepreneurial opportunities. We had argued that individuals' active participa- tion in the economic system (i.e., by being employed rather than being without occupation) may offer the potential to recognize opportunities which are related to one's current business activities. Also, we reasoned that the work place may function as an environment conducive to the development of network contacts with others. One explanation for the lack of an effect of our "work status" variable on opportunity recognition may be that the work environment may be only one of the potential sources of information relevant for start-up activities. That is, most people have many personal contacts with other people through a combination of professional as well as more informal (friends- or family-related) relationships (Burt, 1992; Davidsson and Honig, 2003). Furthermore, we used a rather crude proxy for determining the working experience of our respondents, i.e., being employed (full-time or part-time) versus being unemployed, student, retired or disabled at a given point in time. The work status of an individual - i.e., whether one works or not - is perhaps not as good an indicator for one's propensity to recognize opportunities as his or her specific professional experiences. Future research could thus include a wider range of possible environments (besides the immediate work environment) to which individuals belong and assess the influence of different types of experience (e.g., industry-specific experience, prior experience as entrepreneur) on opportunity recognition.

Finally, it is also interesting to look at the results for our control variables. Interestingly, the regression analysis with the controls for the pooled sample (Model 1, Table II) showed no significant difference between younger and older respondents in terms of the likelihood to recognize opportunities. However, we found that in Belgium younger individuals are more likely to perceive opportunities compared to their older counterparts; one speculative explanation for this finding could be that older employees in Belgium are not encouraged to think "out of the box", and thus are less inclined to perceive opportunities for new business creation. Furthermore, we found that, for the pooled sample, males are more likely than females to be opportunity-minded (Model 1, Table II). This finding is consistent with Crosa et al.'s (2002) finding that gender 
affects the likelihood of business formation. Our results confirm that, especially in Belgium, there may be a huge untapped potential among women in terms of opportunity recognition for start-ups. There are no objective reasons as to why women would be less able than men to recognize entrepreneurial opportunities. Perhaps cultural factors may explain why women are less "opportunityminded" than men in some countries.

\subsection{Limitations, future research and implications}

As mentioned earlier, an important weakness of this study lies in how we related different levels of network cohesiveness to different types of residential areas. Nevertheless, at a minimum level, we have shown that where a person lives does influence the likelihood that one perceives opportunities. It is clear that future research would highly benefit from more fine-grained measures of regional network characteristics and networking opportunities. For instance, regional variation in network density and diversity are both likely to be related to individual-level differences in opportunity recognition (Dubini, 1989; Huggins, 2000). Also, in our study we did not take into account that regions of the same population size (e.g., big agglomerates) may vary greatly in terms of industrial and occupational structure. Future research could examine to what extent the spatial division of labor - whereby different kinds of work and different kinds of workers are located in different places - affects the level of opportunity recognition in a region (Massey, 1995).

Further, prior research has argued that personality differences, e.g., whether an individual is an extrovert or an introvert, affects the extent of one's network, one's reliance on the current set of contacts and the tendency to extend that network in times of need or crisis (Malecki and Poehling, 1999). One could thus expect that personality differences would also influence the likelihood of perceiving entrepreneurial opportunities. In this paper, we focused more on the effect of knowledge-related factors on opportunity recognition. Future research would benefit from combining knowledge and personality related factors to study individual opportunity recognition.
Finally, an interesting result of our study was that the Finnish respondents were much more likely to perceive opportunities compared to their Belgian counterparts. This suggests that there are country-specific factors influencing the perception of entrepreneurial opportunities. Future researchers should compare the drivers for opportunity recognition across a wider variety of countries and cultures than the ones included in this study. This could allow to examine whether cultural factors (e.g., acceptance of uncertainty, social norms) or other factors (e.g., distribution of population density, immigration patterns) affect the extent to which a country's citizens recognize opportunities to start new businesses.

From a practical point of view, our findings suggest that the extent to which individuals perceive opportunities depends on the nature of the residential area to which they belong. Most decisions to start a new venture are quite complex and ask for the access to information from more than a single source. Consequently, individuals who plan to engage in start-up activity need to pool information from a variety of sources. While few persons may be able to search for this information on their own, it is often more expedient to get the information from knowledgeable others (Davidsson and Honig, 2003). Our results gave some indication that information useful for opportunity recognition may be more easily obtained when one resides in a big agglomerate rather than rural area. One potential explanation for the difference between residential areas in terms of the ease with which residents recognize opportunities may be that these areas differ in terms of the channels used to communicate information across individuals. At a general level, public policy aimed at stimulating entrepreneurial activity may need to pay more attention to how different parties, interested in or knowledgeable about entrepreneurship, should be brought together. Although we do not suggest that public authorities should play an interventional role in such a private sphere as individuals' personal networks, government could play a role in creating a general environment that stimulates information exchange among individuals interested in entrepreneurial activity. 
Appendix: Below a description is given of the variables included in this study. The first column gives the name of the variable. The second column describes the variable. All variables have been collected through a phone survey.

\begin{tabular}{ll}
\hline Variable & Description \\
\hline Opportunity recognition & $\begin{array}{l}\text { Response to the question: "In the next six months there will be good opportunities for } \\
\text { starting a business in the area where you live" } 1=\text { Yes, } 0=\text { No }\end{array}$ \\
Age & $\begin{array}{l}\text { Age of the respondent } \\
\text { Binary variable describing the respondent's age: } 0=\text { Male } 1=\text { Female }\end{array}$ \\
Gender & Binary variable describing the respondent's country: $0=$ Belgium $1=$ Finland \\
Nature of residential area & $\begin{array}{l}\text { Categorical variable describing the nature of the respondent's residential area: } \\
1=\text { Rural location } 2=\text { Urban location } 3=\text { Big agglomerate (used as base in }\end{array}$ \\
regressions) & $\begin{array}{l}\text { Categorical variable describing the respondent's educational level: }{ }^{\text {a }} 1=\text { Some secondary } \\
\text { education } 2=\text { Secondary degree } 3=\text { Post-secondary degree (used as base case in } \\
\text { regressions) }\end{array}$ \\
Binary variable describing the respondent's work status: $0=$ Student, homemaker, \\
retired, or disabled $1=$ Full or part-time employed
\end{tabular}

a The values "1" to "3" were assigned to the categories in order to calculate the variable means (Table 1). In the regressions, the categories " 1 " and "2" were entered as binary variables and compared to the base category " 3 ".

\section{Acknowledgement}

The authors would like to thank Edward Malecki and the two anonymous reviewers for their valuable comments. Pia Arenius gratefully acknowledges financial support from the Ministry of Trade and Industry Finland, Tekes and the Academy of Finland (Grant number 207424). Dirk De Clercq gratefully acknowledges financial support from the Ministries of Economic Affairs in Flanders and Wallonia.

\section{Notes}

1 For Belgium, the allocation occurred based on the population size at the locality level (i.e., ZIP code). Rural areas include localities with less than 25,000 inhabitants, big agglomerates include the five main agglomerations (i.e., with at least 200,000 inhabitants), and the urban areas represent the intermediate category (i.e., between 25,000 and 200,000 inhabitants). For Finland, the allocation occurred at the regional level, i.e., based on the proportion of the population living in urban settlements and the population of the largest locality in the region. Rural areas are (a) regions in which less than $60 \%$ of the population lives in urban settlements, and in which the population of the largest urban settlement is less than 15,000, as well as (b) regions in which at least $60 \%$ but less than $90 \%$ of the population lives in urban settlements, and in which the population of the largest urban settlement is less than 4000 . Urban regions are regions in which at least $60 \%$ but less than $90 \%$ of the population lives in urban settlements, and in which the population of the largest urban settlement is at least 4000 but less than 15,000 . Big agglomerates are regions in which at least $90 \%$ of the population lives in urban settlements, or in which the population of the largest urban settlement is at least 15,000 .

2 Although the focus of recent European policy has been on the decrease of economic and social differences across regions in Europe (Stewart, 2002), there are indications that European regions often still differ in terms of important characteristics (Niebuhr and Stiller, 2003). For Belgium, the research focus has often been on the structural differences between the Flemish and the Walloon region in terms of their employment structure and overall economic prosperity (D'Addio and Nicaise, 2003). Furthermore, attention has been given to the case of the Brussels agglomeration in comparison with Flanders and Wallonia, e.g., in terms of its unemployment rate (Marage and Meulders, 2001). Compared to Belgium, the differences between regions in Finland are even more outspoken. More specifically, in Finland the recovery from the recession of the early 1990s has increased the regional differences (Valtioneuvosto, 2000). For example, between 1992 and 1997 the total output grew by $40 \%$ in the capital region, against a national average of $30 \%$. Outside the university cities and particularly in the rural areas, the output rose only by $20 \%$. In big agglomerates the level of employment reached the pre-recession level already in 1998. However, in the rural and in most of the 
urban areas the level of employment is still $15 \%$ short of the pre-recession level. Furthermore, the concentration of production and jobs has spurred migration, which has led to a differentiation in population structure. In big agglomerates, people are young and well-educated. In urban areas the population structure tends to be slightly weaker. Worst-off are the rural areas, in which the people tend to be older and poorly educated.

\section{References}

Aldrich, H. and C. Zimmer, 1986, 'Entrepreneurship through Social Networks', in D. Sexton and R. Smilor (eds.), The Art and Science of Entrepreneurship, Cambridge, MA: Ballinger Publishing, pp. 3-23.

Aldrich, H., B. Rosen and W. Woodward, 1987, 'The Impact of Social Networks on Business Foundings and Profit: A Longitudinal Study', in J. Churchill et al. (eds.), Frontiers in Entrepreneurship Research, Wellesley, MA: Babson College, pp. 154-168.

Bandura, A. 1978, 'Reflections on Self-efficacy', Advances in Behavioral Research and Therapy 1, 237-269.

Barnes, J., 1972, Social Networks, Philippines: AddisonWesley.

Bates, T., 1995, 'Self-Employment Entry Across Industry Groups', Journal of Business Venturing 10, 143-156.

Bates, T., 1997, 'Financing Small Business Creation: The Case of Chinese and Korean Immigrant Entrepreneurs', Journal of Business Venturing 12, 109-124.

Bates, T. and L. Servon, 2000, 'Viewing Self-Employment As a Response to Lack of Suitable Opportunities for Wage Work', National Journal of Sociology 12, 23-55.

Becker, G. S., 1964, Human Capital, Chicago: U. of Chicago Press.

Birley, S. 1985, 'The Role of Networks in the Entrepreneurial Process', Journal of Business Venturing 1(1), 107-117.

Burt, R., 1986, 'A Cautionary Note', Social Networks 8, 205-211.

Burt, R., 1992, 'Structural Holes: The Social Structure of Competition': Cambridge Harvard University Press.

Christensen, P. S. and R. Peterson, 1990, 'Opportunity Identification: Mapping the Sources of New Venture Ideas', Frontiers of Entrepreneurship Research, Wellesley, MA: Babson College, 567-581.

Cohen, W. M. and D. A. Levinthal, 1990, 'Absorptive Capacity: A New Perspective on Learning and Innovation', Administrative Science Quarterly 35, 128-152.

Coleman, J. S., 1988, 'Social Capital in the Creation of Human Capital', American Journal of Sociology 94 (Special Supplement), 95-120.

Coleman, J. S., 1990, Foundations of Social Theory, Cambridge: The Belknap Press of Harvard University Press, MA.

Crosa, B., H. E. Aldrich and L. Keister, 2002, 'Is There a Wealth Affect? Financial and Human Capital as Determinants of Business Startups', Frontiers of
Entrepreneurship Research, Wellesley, MA: Babson College.

D'Addio, A. C. and I. Nicaise, 2003, 'Regional Differences in Belgium: A Point of View', Working Paper, European Union, Employment Observatory.

Davidsson, P. and B. Honig, 2003, 'The Role of Social and Human Capital among Nascent Entrepreneurs', Journal of Business Venturing 18, 301-331.

Dubini, P., 1989, 'The Influence of Motivations and Environment on Business Start-ups: Some Hints for Public Policies', Journal of Business Venturing 4, 11-26.

Evans, D. S. and L. Leighton, 1989, 'Some Empirical Aspects of Entrepreneurship', American Economic Review 9, 519-535.

Grabher, G., 1993, 'The Weakness of Strong Ties. The Lock-in of Regional Development in the Ruhr Area', in G. Grabher, (ed.), The Embedded Firm. On the Socioeconomics of Industrial Networks, London: Routledge.

Granovetter M., 1973, 'The Strength of Weak Ties', American Journal of Sociology 78, 1360-1380.

Granovetter M., 1985, 'Economic Actions and Social Structure: The problem of Embeddedness', American Journal of Sociology 91, 481-510.

Greene, W. H., 1997, Econometric Analysis, 3rd Edition Prentice Hall.

Greene, P. G., 2000, 'Self-employment as an Economic Behavior: An Analysis of Self-employed Women's Human and Social capital', National Journal of Sociology 12, 1-55.

Hosmer, D.W. and S. Lemeshow, 2000, Applied Logistic Regression, 2nd Edition, New York: Wiley.

Huggins, R., 2000, 'The Success and Failure of Policyimplanted Inter-firm Network Initiatives: Motivations, Processes and Structure', Entrepreneurship and Regional Development 12, 111-135.

Ingram, P. and J. C. A. Baum, 1997, 'Chain Affiliation and the Failure of Manhattan Hotels, 1898-1980', Administrative Science Quarterly 42, 68-102.

Johannisson, B., 1990, 'Economics of Overview - Guiding the External Growth of Small Firms', International Small Business Journal 9, 32-44.

Johannisson, B. and M. Ramírez-Pasillas, 2001, 'Networking for Entrepreneurship: Building a Topography Model of Human, Social and Cultural Capital', in Frontiers of Entrepreneurship, Wellesley MA: Babson College.

Kirzner, I. M., 1973, Competition and Entrepreneurship. Chicago: University of Chicago Press.

Lawson, C., 1999, 'Towards a Competence Theory of the Region', Cambridge Journal of Economics 23, 151-166.

Lawson, C. and E. Lorenz, 1999, 'Collective learning, tacit knowledge and regional innovative capacity', Regional Studies 33, 305-317.

Malecki, E. J. and R. M. Poehling, 1999, 'Extroverts and Introverts: Small Manufacturers and Their Information Sources', Entrepreneurship and Regional Development 11, 247-268. 
Marage, F. and D. Meulders, 2001, 'Evaluation of the Belgian Action Plan for Employment 2001', European Commission, Expert Group of Gender and Employment (EGGE).

Massey, D., 1995, Spatial Divisions of Labour: Social Structures and the Geography of Production, London: MacMillan.

Nahapiet, J. and S. Ghoshal, 1998, 'Social capital, Intellectual Capital, and the Organizational Advantage', Academy of Management Review 23, 242-268.

Niebuhr, A. and S. Stiller, 2003, 'Territorial Disparities in Europe', Intereconomics 38, 156-164.

Podolny, J. M., T. E. Stuart and M. T. Hannan, 1996, Networks, Knowledge, and Niches: Competition in the Worldwide Semiconductor Industry, 1984-1991. American Journal of Sociology 102, 659-689.

Prahalad, C. and R. Bettis, 1986, 'The Dominant Logic: A New Linkage Between Diversity and Performance', Strategic Management Journal 7, 485-501.

Reese, P. and H. Aldrich, 1995, 'Entrepreneurial Networks and Business Performance: A Panel Study of Small and Medium-sized Firms in the Research Triangle', in S. Birley and I. Macmillan (eds.), International Entrepreneurship, London: Routledge, pp. 124-144.

Reynolds, P. D., N. S. Bosma, and E. Autio, 2005, 'Global Entrepreneurship Monitor: Data Collection Design and Implementation 1998-2003', Small Business Economics, in press.

Shane, S. 2000, 'Prior Knowledge and the Discovery of Entrepreneurial Opportunities', Organization Science $11,448-469$

Shane, S. and S. Venkataraman, 2000, 'The Promise of Entrepreneurship as a Field of Research', Academy of Management Review 25, 217-226.
Singh, R., G. E. Hills, R. C. Hybels and G.T. Lumpkin, 1999, 'Opportunity recognition through Social Network Characteristics of Entrepreneurs', Frontiers of Entrepreneurship Research. Wellesley, MA: Babson College.

Stevenson, H. H. and J. C. Jarillo, 1990, 'A Paradigm of Entrepreneurship: Entrepreneurial Management', Strategic Management Journal 11, 17-27.

Stewart, K, 2002, 'Measuring Well-being and Exclusion in Europe's Regions.' 'Case Paper', No. 53' London School of Economics.

Stynes, D. J. and G. L. Peterson, 1984, 'A Review of Logit Models with Implications for Modeling Recreation choices', Journal of Leisure Research 16, 295-310.

Valtioneuvosto, 2000, 'Alueellinen kehitys ja aluepolitiikka Suomessa', Valtioneuvoston kanslia sarja, 6 (in Finnish) (A English summary: Regional Development and Regional Policy in Finland. 2001. Prime Minister's Office: Publications).

Venkataraman, S., 1997, 'The Distinctive Domain of Entrepreneurship Research', in J.A. Katz (ed.), Advances in Entrepreneurship, Firm Emergence, and Growth, Greenwich, CT: JAI Press, pp. 119-138.

Waldinger, R., H. E. Aldrich and R. Ward, 1985, 'Ethnic Business and Occupational Mobility in Advanced Societies', Sociology 19, 586-597.

Zaheer, A., B. McEvily and V. Perrone, 1998, 'Does trust matter? Exploring the Effects of Interorganizational and Interpersonal Trust on Performance', Organization Science 9, 141-159. 